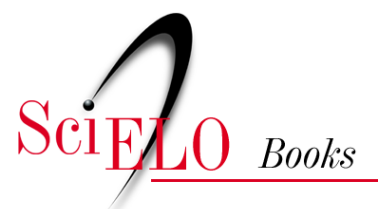

\title{
2. As nervosas do Campeche e suas queixas
}

\author{
Maria Lucia da Silveira
}

\section{SciELO Books / SciELO Livros / SciELO Libros}

SILVEIRA, M. L. As nervosas do Campeche e suas queixas. In: O nervo cala, o nervo fala: a linguagem da doença [online]. Rio de Janeiro: Editora FIOCRUZ, 2000. Antropologia e saúde collection, pp. 45-60. ISBN: 978-85-7541-609-9. Available from: doi: $10.7476 / 9788575416099.003$. Also available in ePUB from: http://books.scielo.org/id/k4vp7/epub/silveira-9788575416099.epub.

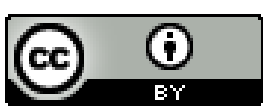

All the contents of this work, except where otherwise noted, is licensed under a Creative Commons Attribution $\underline{4.0 \text { International license. }}$

Todo o conteúdo deste trabalho, exceto quando houver ressalva, é publicado sob a licença Creative Commons Atribição 4.0. 


\section{2}

\section{As Nervosas do Campeche e suas Queixas}

Propositadamente, privilegiei como ponto de observação a perspectiva do sofredor, razão pela qual utilizo o termo paciente para os sofredores dos nervos, enfatizando-os como sujeitos do sofrimento, e reservo informante ${ }^{1}$ para as outras pessoas da comunidade que colaboraram com a pesquisa.

Entrevistei 13 mulheres, de idades variadas e de histórias diversas, reunidas sob um rótulo comum: nervosa. A condição para inclusão no grupo era a mulher ser reconhecida por si e pela comunidade como sofredora de nervos. Dessas, dez foram entrevistadas individualmente, uma ou até cinco vezes, dependendo de sua disponibilidade, e uma delas me brindou com um texto que responde a algumas perguntas sobre a natureza do seu sofrimento. Outras três encontrei uma única vez, numa reunião do Grupo de Mulheres do Campeche, e a conversa sobre nervos, embora feita com uma de cada vez, deu-se no meio das outras participantes e com freqüentes intervenções destas. Eram casos de mulheres que já haviam sofrido dos nervos, mas haviam melhorado após a menopausa (um caso) ou após a separação do marido (dois casos).

Entre as dez primeiras, entrevistadas individualmente, havia sete casos em curso e três que informaram ter sofrido dos nervos uma vez e haver sarado.

A idade das mulheres, à época da entrevista, variava de 25 a 56 anos. O aparecimento do problema de nervos de uma se deu aos 12 anos de idade; para outra, aos 14; para uma terceira, aos 20 (as três eram solteiras ao tempo desse episódio). Todas as outras iniciaram seus problemas com mais de 20 anos e já casadas, algumas após a menopausa. Do conjunto, a mais nova e a mais velha eram solteiras, nunca se haviam casado ou tido filhos. Entre as demais, nove eram casadas ou amasiadas (uma das quais se casou novamente após uma viuvez) e duas eram desquitadas.

Não observei correlação entre o número ou a idade dos filhos e o surgimento de sintomas. As duas solteiras (uma de 23 e a outra de 51 anos) não os tinham; quanto às outras, tinham de 1 a 6 filhos, cujas idades variavam de 4 a 40 anos (daí se depreende que alguns nasceram de mães adolescentes). A continuidade da pesquisa revelou que, por aqui, o casamento para elas se deu - tal como entre as suas mães - a partir dos 15 anos; os pais, ainda hoje, forçam para que isso aconteça o mais cedo possível, tão $\operatorname{logo}$ as meninas ultrapassem a puberdade. 
Todas residiam em casa própria, cujas condições de conforto variavam, mas tinham luz elétrica e os equipamentos sanitários essenciais (água encanada e instalações sanitárias mínimas, em boas condições). Entre elas, sete não trabalhavam fora de casa, duas eventualmente tinham emprego ou trabalho, três tinham emprego fixo e uma era professora de primeiro grau, aposentada. À exceção de uma delas, cujo marido era pedreiro e alternava períodos de emprego, com bom salário, a outros, às vezes longos, de desemprego, durante os quais quem se vira é ela, e de outra, cuja família era a mais numerosa e o marido, aparentemente, alcoolista, as outras não passavam por grandes problemas financeiros. Não se pode, portanto, ligar fortemente o quadro clínico a condições materiais de vida, embora nem sempre a percepção das pacientes a respeito coincidisse com a da pesquisadora.

Todas as entrevistadas relataram o problema de nervos como vivenciado por elas mesmas. A esse relato, vez ou outra acrescentavam informações ou faziam comparações com outros casos, em geral de parentes seus, que também sofriam de nervos. À exceção de três delas, todas as outras experimentavam a doença como crônica, estigmatizante, mas que não as incapacita. O estigma advém da desqualificação pela qual passam, uma vez que as crises são visíveis, levando-as ao descrédito ou, ao menos, dando aos outros o direito de duvidarem de si, como elas próprias reconhecem: "claro, né? Quem é que pode saber se amanhã eu vou ter cabeça boa para fazer uma coisa assim que exija mais?" (Paciente).

Quanto à duração dos casos, uns se arrastam por mais de 20, 30 anos, um por nove anos, outros duraram alguns meses. Tanto os mais longos quanto os mais rápidos se caracterizaram por se darem em crises recidivantes, às vezes com variações completas na sintomatologia e nem sempre facilmente associáveis a outros episódios críticos em suas vidas, de forma que pudessem ser a eles atribuídos. Como disseram as pacientes,

Passei muito trabalho na vida, agora que sosseguei apareceu a doença. Se fosse de trabalho... mas às vezes estou assim num baile, numa festa, está tudo calmo, era para estar tudo alegre, aí não sei o que é, parece que a gente relaxa e aí dá a crise... (Paciente)

Na terceira gravidez é que eu tive a crise, e isso é que eu não entendo, não sei se a senhora podia me explicar, por que quando tudo aconteceu [o marido ter amantes, beber muito e desperdiçar o seu salário], tudo tava na pior eu não tive nada e depois, tanto tempo depois, é que eu fui ter problema. (Paciente)

Embora em alguns casos, ou em diferentes episódios na mesma paciente, haja um acontecimento marcante, com alto potencial estressante, como uma doença, um acidente ou outro fato grave na família ou na vizinhança, seu aparecimento é imprevisível do ponto de vista dessas mulheres. Isso constitui uma de suas grandes marcas e gera muita insegurança, alterando o ritmo de suas vidas, por criar um eixo permanente de preocupação pela iminência constante de elas virem a sofrer nova crise. Também com certeza representa um sofrimento adicional: o de viverem ameaçadas por uma possibilidade de evolução desfavorável, trazendo-lhes implicações concretas em suas vidas e projetos: 
As crises dão sem que eu pense em nada, pode ser na alegria, numa festa por exemplo, no meio de gente, sem nada para me aborrecê, não precisa de nada pra dá... parece até que quando a gente relaxa dos poblema, está para sentir alegria, é que vem! (Paciente)

No que outras pacientes estão de pleno acordo:

Às vezes eu tenho raiva de mim por sofrer dos nervos, porque uma pessoa que tem esse problema ela não consegue ter muita segurança, a gente vive meio ligada no que pode nos ocorrer e os nervos em todas as formas... (Texto de uma paciente)

Volta e meia estava numa boa, depois parecia que ia morrer. (Paciente)

Não precisava ter motivo, não precisava acontecer nada. Era uma coisa tola, sei lá. (Paciente)

As sofredoras de nervos são mulheres tidas na sua comunidade como "trabalhadeiras, caprichosas, que gostam de ajudar os outros"; seu sofrimento, ou melhor, suas causas, são meio incompreensíveis para as outras pessoas. Essa dificuldade de aceitar o sofrimento expressava-se na sua própria fala e na das vizinhas, e fundamentava-se no que elas próprias apontaram e também no fato de que nenhuma delas passava no momento por grandes carências materiais. Embora algumas das pacientes houvessem, vez ou outra, passado por dificuldades dessa natureza, apenas em uma delas isso ligava-se à primeira crise de nervos, provavelmente como fator coadjuvante. Faltava dinheiro, no seu entendimento, em decorrência de alcoolismo, de doenças ou de casos extraconjugais dos maridos, que os levavam a fazer gastos extraordinários fora do lar.

O constante nesses relatos é que elas também qualificam a si mesmas como pessoas bondosas, sempre dispostas a ajudar os outros. Essa é uma das razões pelas quais se sobrecarregam de atividades, o que muitas vezes gera frustrações e sensação de menosprezo, pois esperam reconhecimento e retribuição espontânea a seus gestos. Algumas das crises parecem se dar justamente na tentativa de reverter a situação de abandono ou de desvalorização que vivenciam:

Sempre gostei assim de ajudar, mas não tinha como (...) e tudo que eu faço para os outros não tem valor pra ninguém, né? Eu sinto assim, em mim, que as pessoas não gostam de mim, tudo que eu faço... Eu procuro é ajudar. Até hoje [que sou doente], gosto de ajudar, às vezes não tenho meios, não consigo, fico presa... Mas ainda assim mesmo gosto de ajudar. Mas sinto não poder.. Sinto também porque as pessoa não dá valor ao que eu faço, trago isso desde pequena, sinto e sei que é assim (...) manda as menina buscar a roupa que eu vou deitar para não cair, senão eu vou cair, porque a minha cabeça está rodando, assim, ó!

Suas vizinhas reconhecem:

Ela [uma paciente] gosta demais de ajudar todo mundo, coitada! Está sempre fazendo o bem para os filhos, os vizinhos. Mas parece que ninguém dá valor, o marido, esse, então, nem se fala... Ela se queixa e com razão, acho até que a doença dela é por causa disso... (Informante) 
Nesse aspecto, lembram o registro de Lock (1991b) a respeito da honra ligada aos papéis femininos e às suas normas de conduta entre imigrantes gregas no Quebec. A retribuição esperada pode vir por meio da aquisição de objetos cobiçados:

Ah, eu queria um sofá novo, mas não era qualquer um não, que o meu pai, de pena de mim, comprou um, mas não era aquele, aí o meu marido não queria comprar, ai eu não sei o que me deu, aquele nojo, igual o nojo que sinto das coisas velhas dentro de casa, aí eu comecei a chutar tudo, a batê pra quebrá, fiquei louca, disse para ele [para o marido] eu faço tudo, ajudo todo mundo e nem posso ter um sofá do jeito que eu quero! O que adianta fazer de um tudo para vocês? Ele disse tá bom, vamos comprar o que você quer! (Paciente)

Hoje [depois que apareceu o problema dos nervos], meu marido me deixa fazer o que eu quero, o dinheiro dele fica na minha mão, eu compro o que quero, não preciso pedir para ele, antes não era assim, ele ia pro bar ou gastava com aquela outra, nem adiantava saber que eu estava ali, em casa, fazendo tudo por ele e por quem precisasse, não valia nada ser boa... (Paciente)

Demonstram também que a sensação de abandono é percebida também em relação a sua sintomatologia e se relaciona à atitude dos familiares, bem como à dos profíssionais de saúde:

Já estou cansada de falar pros médico, psicólogo, tudo! Mas eles também não ligam para o que a gente sente! É igual meu marido e os filhos, acham que a pessoa quando se queixa está inventando tudo... (Paciente)

Ah! Eu queria é isso mesmo, que ele me pusesse no colo, me agradasse... Quando estou atacada, se ele, ou outra pessoa, faz isso, eu me sinto tão bem! Parece assim que é isso que tá faltando... (Paciente)

A sintomatologia, nesses casos, assim como observara antes em minha experiência em clínica médica e na literatura, é rica, e sua descrição comporta meandros polimórficos. Tais meandros levam a detalhes do cotidiano das pacientes, a um esmiuçamento de relações extremamente férteis em informações psicossocioculturais que fornecem as pistas para o tripé interpretativo aqui proposto para nervos:

Às vezes parece uma coisa que vem daqui [mostra a região do coração], e a preocupação que me atrapalha, às vezes parece uma coisa que me atrapalha, aqui dentro [regiões esplênica e pré-cordial], que vem de dentro de mim, assim... É um aperto, uma atrapalhação que eu passo desde pequena. Afinal de contas, eu sou uma pessoa de sofrer sem reclamar, não sou de contar isso pra ninguém, de desabafar, né? Eu sou uma pessoa doente desde a minha infância, compreendes? Eu sofri assim de calorão, de frio doído, de viver chorando pelos cantos, tinha medo, um medo, tu sabes o que é um medo de temporais? De gostar sempre assim de querer ajudar, mas não tinha como ajudar, e de tudo que eu fizer não ter valor pra ninguém, né? Eu sinto assim em mim que as pessoas não gostam assim de mim, tudo que eu faço, vamos supor se eu for ajudar, elas acham ruim... que se eu for ajudar eu só quero ajudar, que eu procuro é ajudar se eu posso, mas o que eu faço as pessoas não dão valor, que eu sinto, eu noto isso; eu trago isso desde pequena e sei cque é assim... (Paciente) 
Na morte do meu primeiro marido, eles não me prepararam, não me disseram um nada assim pra me preparar, eu tava grávida do filho mais moço e eles chegaram assim e disseram que ele tinh a morrido na água, lá na Lagoa da Conceição, que às vezes ele ia pescar lá, que ele pescava mesmo era no mar, vivia de ser pescador. Eu sei que eu fiquei presa, eu lembro que eu dava pulo assim [eleva o braço, mostrando perto do teto], parece que eu tava como quem tá louco, parece que eu tava louca... Parece que eu não caía mais. Ninguém me dava um nada, nem me dava um chá nem me dava uma palavra amiga... Eu não vi se tinha ninguém, dizem que a casa estava cheia, eu não vi nada, ninguém. Só sei que tinha gente que conversava porque eu escutava a voz, só não sei quem era, porque não era comigo, comigo eles não falavam. (Paciente)

A minha vizinha, quando tem crise, fica sufocada, diz que tem muitas dores que começam por baixo, no útero, no ovário, não sei... Depois parece que ela não pode respirar, o coração dispara, se alguém falar meio áspero com ela, vira bicho, parece um animal que vai pular nos outros, acho que ela fica assim por causa do marido que vive meio bêbado por aí, e dos filhos que não obedecem mais ela, mas também ela quer que eles sejam que nem ela quando era moça... Não entende que a juventude hoje é diferente. Sei que é feio quando ela está atacada, parece que vai morrer, na mesma hora já parece um não sei o quê, parece que alguma coisa toma conta dela, fica com uma força... Padece muito, tadinha... E os filhos, esses nem ligam, nesse ponto ela tem razão de mangar com eles, né? (Informante)

Uma vez, antes disso, fiquei assim, sem poder falar: foi um susto. Eu estava esperando a segunda filha e tive um susto porque tinha época que eu tinha medo, tinh a um incômodo na cabeça, um medo que eu não ia no pátio da frente quando ele não estava em casa; mas também eu não contava pra ninguém, só pras minhas irmãs e guardava pra mim. E um dia eu tava sentada, fazendo renda, numa cadeira bem baixinh a fazendo renda assim, e no que eu levanto a cabeça deu um estrondo, sabe assim como se caísse uma coisa fora do lugar, mas um estrondo bem forte, não tem? Como se caísse uma coisa, mas bem mais forte, né? Um barulho assim que parece que desabou o mundo inteiro, aí me arrepiou toda assim, também não sei o que era, porque não caiu nada... A gente passava aquele susto, mas não caiu nada, nada. Ai eu peguei três hemorragias nessa gravidez, mas também não contei para ninguém, não fui pra maternidade, nada, fiquei em casa; na última então eu mandei chamá minha madrasta, porque essa gente antiga assim sabia muito remédio, ai ela veio fazer um remedinho pra mim, aí, graças a Deus, passou tudo. (Paciente)

Essa minha prima tem crise volta e meia, por isso que anda louca atrás de médico que dê a receita azul, não fica sem ter remédio forte em casa. A última crise foi a da fulana [cita o nome da última amante do marido da paciente], ela desanda a gritar e diz que fica com nojo de tudo que é velho em casa, começa a quebrar tudo, ai o marido tem que comprar tudo novo, senão ela não pára de ter crise. Mas se ela estiver tomando os remédio azul, aí ele pode fazer o que quiser, que não acontece nada com ela, nem liga se ele tá com outra ou não. (Informante) 
A crise descrita acima por uma parente, agora contada pela própria paciente:

Meu nervo começou quando meu marido botou uma porta, né? Ele comprou uma porta e botou lá em casa, depois que ele colocou a porta... que eu não sentia nada, e depois dos três filhos, ele colocou a porta e eu comecei a passar mal. Ele saiu pro jogo e começou a me dar a crise. Só que a minha crise era os pés ficarem dormentes, as mãos... Eu me sentia agoniada, só gritava, só gritava, só gritava, e quanto mais gritava, mais vontade dava de gritar, mas eu não tinha aquela vontade de avançar, de bater, não tinha aquilo, sabes? Depois, com muito tempo é que eu fui criando um nojo das coisas que eu tinha dentro de casa. Eu não podia ver nada velho dentro da minha casa, aí eu queria meter os pés, eu chegava..., eu não podia ver... Eu queria tudo novo, até o dia que eu quebrei duas cadeiras e a mesa e fiz meu marido comprar uma mesa nova [radiante] e até hoje eu não consigo viver sossegada com uma coisa velha. Aífui no médico, o médico disse que eu não podia tomar calmante, que eu não tinha [enfática] nada nos nervos! Aí eu comecei com uma dor na bexiga, que eu não conseguia usar minhas pernas, com dor aqui do lado [aponta a região inguinal direita], que precisou de três pessoas para me levar no hospital, meu irmão veio. Eu não tinha dinheiro para pagar [dramática] um carro, ele pagou para mim. Só que mudou muita coisa depois do remédio, mas depois começou assim: eu olhava pros meu filhos e parecia assim que en ia morrer, e ia deixar meus filhos, ai me clava vontade de chorar e vinha aquela coisa ruim, e eu sentia uma coisa assim ruim, ruim, depois de muito tempo que tomei remédio, dois anos. Eu acho que de uns quatro anos pra cá é que eu fiquei mais ou menos, mas mesmo assim eu me sinto assim, que eu queria ter uma vida melhor. Aí o meu marido começou a me trair, me traiu sete vezes! A última vez me traiu com uma velha de 50 anos! [risos]. Porque 50 anos hoje... Pô! Tem mulher que tem 50 anos que... mas ela não, ela é uma velha nojenta! Ele teve um ano intero com ela, eu aceitei tudo isso, eu aceitei ele de volta, por causa dos filho (...) mas... até hoje eu não aceito, eu queria ter uma vida melhor, queria ter as coisas dentro de casa melhores, que ele botou muito dinheiro fora... Ele saía, perdia na rua... E tudo isso... Eu acho que em veis de melhorá eu compliquei tudo... Mas eu nunca pensei assim que eu vou tomar uma caixa de remédio pra tudo se acabar, que eu vô tomá um veneno porque eu tenho que me matar, eu nunca pensei assim, né? Que tem gente que pensa isso, né? Eu, se eu não tomar o remédio, eu não consigo dormir, eu fico sem dormir a noite inteira! Aí eu começo a pensar: o que que eu vou fazer amanhã, se vou ter o dinheiro pra comprar o pão, o que que meus filho vão comer? Se meu marido está trabalhando, tudo bem, se não... Agora, se meu marido está trabalhando, eu sou uma pessoa, se tá desempregado, sou outra... Sabe, eu sou bem assim... Não sei... E se eu estiver trabalhando, a minha doença fica lá no serviço, eu venho para casa boa, eu não sei se é porque quando eu estou trabalhando eu tenho meu dinheiro, vou comprar o que que eu quero! E não fico pensando essas coisa boba, não! A doença sai de mim! (Paciente)

Presenciando a conversa entre ela e uma amiga, confirmo que os nomes das amantes do marido designam as crises de nervos, e que estas aparecem quando ele tem mulher na rua, gasta muito com ela, deixando a família em má situação. Nessas ocasiões é que ela garra nojo das coisas que tem em casa, fica atacada dos nervos, quebra tudo 
e obriga o marido a comprar novos objetos e, conseqüentemente, deixa-o sem condições materiais de manter a amante. Como eu já entrevistara como nervosa a que emprestou o nome para a última crise dessa paciente, em outra ocasião procuro sua amiga para saber sobre o problema da amante. Sua resposta mostra como a comunidade efetivamente lê alguns significados nas crises:

Se ela também sofre dos nervos? [risada que mostra discordância] $O$ que ela tem? É assanhada que só, é separada e vive por aí nos baile, se mete com tudo quanto é homem... Ih, precisas ver o que tem de história dela por aí... Uma hora vamos sentá e eu te conto... E ela tem crise mesmo nas festas, mas é porque se mete com o marido das outras e ai tem que ter um ataque pra livrar a cara!

As próprias pacientes indicam outros sintomas e situações associadas, por vezes, à leitura que fazem da sua própria crise de nervos:

É só alguém gritar que tem alguém doente, mesmo que eu não conheça, ou outra notícia ruim, uma morte, por exemplo, que já vem o problema, fico ruim, tenho que vomitar, fico zonza, dá uma tremedeira, tenho que correr para o banheiro, aí passa, é só vomitar que eu já melhoro... [A filha intervém, novamente reforçando sua opinião de que a mãe apenas padece de ansiedade]. ${ }^{2}$ Passei muito trabalho na vida, agora que sosseguei apareceu essa doença. Se não tomo o remédio, já começa a parecer, arroxear tudo... Não dói nem nada, mas fica muito feio, todo mundo vê, parece que eu apanhei, mas nem tenho homem ${ }^{3}$ desde que me separei. Tinha crise de bronquite quando era criança até mais ou menos oito anos atrás, tomava Filinasma®, tomei três anos sem parar, a bronquite passou antes um pouco de eu me separar. (Paciente)

Eu, quando me dá a crise, só quero ficar deitada, quero chorar sem motivo, não quero que ninguém fale comigo e eles [marido, filhas e, eventualmente, amigos ou outros parentes] ficam no desespero, não sabem o que fazer: Mas hoje em dia parece que eles não agüentam mais me ver assim, dizem que é pra eu reagir, sair, fazer alguma coisa, que está tudo bem. Meu marido diz assim: o que você quer que eu faça? Te ponha no colo, faça cafuné? (Paciente)

Desde a primeira crise, quando eu tinha 12 anos, vinha uma coisa pelas pernas, subia, parecia que a cabeça ia estourar, parecia que ia morrer; às vezes dava raiva, às vezes dava para chorar; não conseguia dormir; quando vou ao médico eu explico que parece que tenho um grande susto dentro de mim, fico perplexa, parada. Quando vai dar, sinto uma depressão, uma tristeza; antes não conseguia me controlar, tinha que tomar injeção, remédio; agora faço algumas coisas e me controlo. Dá de várias formas. Às vezes tenho que vomitar, pôr para fora. Para ser sincera, uma coisa horrível! Como se eu saísse fora do ar. Se eu acreditasse, às vezes parece que é uma coisa ruim que tá na gente. (Paciente)

Ah, é um negócio horrivel, tem tanta coisa que a gente sente, chega a ter vez que eu já cheguei a ir no posto ${ }^{4}$ andando assim parece um boneco, toda desmontada, toda desconjuntada, as mulheres [funcionárias e pessoas que estão à espera de consulta no posto de saúde] diz: tem coragem, tem coragem! Que coragem que nada! É um negócio horrivel, tenho que agüentar sozinha, vou lá pra cama e me 
deito e não me levanto, tem veiz que tem que deitá de barriga pra baixo, tem hora que tem que ficar de barriga pra cima, tem hora que tem que gritar; tem hora que tem que rir; tem hora que tem que chorar. Tem as vezes que eu gosto de ficar perto de alguém, assim com as meninas, mas elas sabem que eu não gosto que faça pergunta. (Paciente)

Outros sintomas mencionados: embucho, aperto na garganta, sensação de morte iminente, tremedeira, insônia, medo de morrer, avião roncando dentro da pessoa, dor de cabeça, ruindade por dentro, bola na garganta que sobe e desce (tanto na garganta quanto na barriga e, eventualmente, no tórax), ${ }^{5}$ tristeza profunda, ficar com a cabeça leve, sensação de que a cabeça vai rodando, dormência nos pés elou nas mãos, sentir agonia, vontade de gritar e, em alguns casos, impossibilidade de fazê-lo, como uma paciente que diz que nas crises não pode falar, sente vontade de gritar mas só consegue soltar um guincho, como um animal.

Desse caleidoscópio sintomático, que tanto é individual (pois varia de uma crise para outra e dentro de uma mesma crise) quanto varia de paciente para paciente, deriva a dificuldade, anteriormente apontada, de se estabelecer um padrão que defina o que é uma crise de nervos.

Os ciclos relacionados à fase reprodutiva da mulher são percebidos como diretamente ligados à gênese das crises. Porém, as pacientes discordam quanto ao comportamento da doença durante as várias fases, especialmente no tocante à gravidez.

Diz uma delas:

Quando estava grávida, acho que é uma bênção divina, eu não tive nada, não precisei de um comprimidinho sequer. Eu sempre quis ter um filho e quando fiquei grávida não quis tomar nada. Depois só tive crise quando ela [a filha] tinha um ano e meio quando o pai dela morreu. Fiquei mais de dois anos sem crise. (Paciente)

Enquanto outra:

Todas as minha gravidez eu passava mal, desde o primeiro dia; naquele dia que ficava grávida parecia que acabou o mundo. Pra ficar grávida, ficava fácil; mas não sei se era dos nervo, depois... Era dor demais, né? Ficar grávida era preparar o sofrimento, a dor, mas dor mesmo, demais! E ficava abatida, tinha algo diferente, assim parece que acabou-se tudo pra min, os nervos decerto, só podia ser, nunca tinha dado pensamento nenhum em mim... Só podia ser nervo, né? E foram sofridas, todas as minha gravidez foi sofrida. (Paciente)

A primeira crise me deu na terceira gravidez, os problemas já tinham passado, não entendo por que começou isso. Uns dizem que eu rejeitei, está certo, eu não queria engravidar.. Até hoje, que já estou na menopausa, tenho medo de engravidar, Deus me livre! Ele é que evita [coito interrompido], que hoje em dia ele é muito bom pra mim... Então dizem que eu adoeci porque eu rejeitei, mas eu não acho que rejeitei a minha filha, não fiz nada assim pra abortar.. Não tomei um chá, não fiz nada... Mas não sei por que me deu os nervos... (Paciente) 


\section{E em relação à menstruação:}

Na última vez que deu a crise, estava pra ficar menstruada, parece que tem uma leve tendência com ela [a menstruação], fica mais nervos. (Informante)

Se suspende [a menstruação], pode provocar qualquer coisa na mulher, tem umas que ataca os nervos, que nem a que mora ali, ela sofre muito por isso e volta e meia ela tem suspensão... (Informante)

Muitas crises ela teve porque não se cuida, toma friagem ou lava a cabeça quando está menstruada ou a regra está para descer.. Aí não tem jeito, no mesmo dia já ataca os nervos, também não se resguarda como uma mulher tem que fazer... (Informante)

Uma vez ela lavou a cabeça, tava menstruada, deu uma crise de nervos muito forte; quando a gente foi saber, tava internada no hospital. (Informante)

A mesma disparidade quanto à importância na gênese e ou na manutenção das crises pode ser observada em relação à menopausa. A paciente, cujo caso era o de sintomatologia mais exuberante e apresentava as crises mais freqüentes, sendo reconhecida também pela comunidade como o caso mais grave, contou sua experiência com este evento:

Agora na menopausa, o que que eu quero, né? Não tem que ser honesta? Tem que ser honesta, né? Aí a menstruação começou a faltar, né? Que ela nunca atrasava, era sempre adiantada, e tinha lá um mês que vinha duas vezes no mês, aí começou a faltar, com 44 anos. Chegava os dias, começava a vim um poquinho, vinha aquele poquinho e eu deitada, não podia fazer nada, mas eu não posso ficar deitada, não posso caminhar, não posso fazer nada, não posso falar, nem deitar de barriga pra cima, que parece que dá um negócio assim, parece que o coração parece que abafa... Vai fazê três meses, foi quando a menstruação começou a faltar. Porque é assim: a minha menstruação começou a faltar com 44 anos, com 44 anos eu me lembro muito bem, eu fiquei menstruada e daí eu não sei, por nada, por nada, não sei contar por que eu não me incomodei com nada nem com ninguém, eu sei que, como dizem os antigos, suspendeu, ai eu fui vermelhando, vermelhando, com aquela dor, aquela dor, que já dava de solteira, aquilo fica lá dentro, estorva, estorva, estorva, não dá pra dizer o que que é, né? (Paciente)

Para umas, as que sofrem desde cedo, o problema parece que alivia quando as regra se acabam, mas pra mim foi o contrário, eu era boa de tudo até que começou a suspender, aí, quando era tempo de vim e não vinha, me dava uma ruindade, um vermelhão, parecia que ia sufocar, até agora, dá isso nos dia que era de vim as regra... Já faz, três anos que não vem mais, mas o calorão, os nervos, isso continua nos dia certos... Parece que o corpo sente e daí ataca até a cabeça... Parece que ficou sujeira no corpo da gente que precisa sair e não tem mais por onde, daí ataca... Acho que sobe pra cabeça, por isso que dá nos nervos. (Paciente)

Para outras pacientes, as coisas se dão desta forma:

Pra mim foi diferente, sofri muito até suspender, eu ficava atacada, sou professora e nem podia dar aula quando tinha os nervos, sei lá, acho que se eu fosse para a sala de aula era capaz de matar um aluno de tão fora de mim que eu ficava, 
geralmente me atacava mais quando tava menstruada. Aí quando foi parando foi aliviando, agora faz dois anos que não tive mais nada. Também me separei do marido, não sei se foi uma coisa ou outra, mas teria sido bom se minha doença tivesse sido ao contrário, eu não teria tido tanto problema na escola. Agora estou aposentada mesmo, tanto faz que tivesse crise ou não. (Paciente)

Em geral, suas queixas mórbidas se entremeiam com as de natureza sociorrelacional, como já se pôde observar em alguns dos exemplos citados, e apontam para o estigma associado ao sofrimento dos nervos e aos privilégios que a situação de nervoso confere.

\section{a Etiologia Explicada pelas Pacientes}

As causas propostas pelas pacientes e pela comunidade para os nervos são várias e, segundo elas, pode acontecer que duas ou mais concorram para o aparecimento do problema. As mais citadas podem ser agrupadas, segundo sua natureza, em causas hereditárias, em problemas relacionados aos ciclos femininos (menstruação, gestação, puerpério, menopausa), fraqueza constitucional (que nem sempre se ligaria a fatores hereditários, seria uma espécie de qualidade individual, inata mas não herdada, que inclui tanto a fraqueza orgânica quanto a afetiva ou moral, como a das pessoas fracas, que não podem ver o sofrimento alheio, as injustiças, sem adoecer também), deficiências alimentares, excesso de problemas materiais ou afetivos, susto, ${ }^{6}$ inveja, causas transcendentais ou religiosas (ação de espíritos, trabalhos feitos contra alguém, possessão demoníaca, vontade divina, culpa por pecados e erros etc.), excesso de trabalho físico ou mental, fraqueza moral e, finalmente, falta de homem (de relações sexuais) e, ainda, contágio, em outro caso.

Essa profusão de etiologias, entrecruzadas na maioria das vezes, reflete-se nos itinerários terapêuticos adotados, que, por sua vez, também lançam mão de práticas muito diversas, visando a atender a cada um dos modelos explicativos da doença.

O modelo explicativo final, que resulta de vários cruzamentos de modelos absolutamente diversos e, por vezes, conflitantes entre si, pode ser exemplificado num único caso, ouvindo-se tanto a paciente quanto sua mãe:

Minha mãe diz que a primeira crise, quando eu tinha 12 anos, foi por causa de um susto: eu estava numa kombi que meu pai tinha, com o meu irmão dormindo em meu colo, e pensei que ele tinha morrido porque eu não conseguia perceber a sua respiração; um mês depois tive a primeira crise.

Na última vez que deu a crise, estava pra ficar menstruada, parece que tem uma leve tendência com ela [a menstruação], a pessoa fica mais nervosa. (Paciente)

Acho que eu tenho assim uma fraqueza, dentro de mim, sei lá, é uma coisa da pessoa mesma, parece que alguns têm, outros não, não sei explicar por que, mas é assim, veja lá em casa, eu tenho essa fraqueza, minhas irmãs não, não sofrem nada... (Paciente) 
Às vezes eu penso que seja hereditário: a minha tia, irmã de meu pai, sofria dos nervos, a minha prima também, desde criança, a gente brincava junto e parece até que começamos a sofrer juntas... A minha avó dizia que era por causa de um trabalho que a namorada do meu avô fez contra ela, coisa feita com coisa de cemitério, trabalho muito forte, então eu e a minha prima, que éramos crianças naquele tempo, brincávamos no quintal da casa dela, onde a talzinha tinha enterrado coisa de cemitério, um trabalho contra a vó, que casou com o namorado dela, né? Aí nós, que éramos mais fracas do que os grandes, pegamos os nervos por causa disso... [por serem crianças e, por conseqüiencia, fracas]. (Paciente)

Aí acho que ela ficou com aquele susto dentro dela, um impacto, né? Depois comeu caqui, e o médico disse que foi do caqui que deu isso, eu acho que foi do susto, cada vez que ela leva um susto assim de alguém que morreu ou ficou doente, tem problema, já volta tudo. O susto provoca o sistema nervoso da pessoa, onde a pessoa fica assim, se rompe por dentro dela, já não presta mais. (Mãe)

Mas a mãe mesmo, a cada momento, apresenta uma outra explicação:

Acho, às vezes, que é falta de alimentação, tem época que se alimenta mal, dá isso, parece uma fraqueza que ataca tudo...

Ela puxou a familia, é hereditário. O pai também é nervoso, loucão, tem dois comportamentos: um para as pessoas de fora, estranha, vai parar na cidade, é conhecido, em cada canto alguém fala com ele, pros estranhos ele é delicado, trata com carinho; é outro para a família, aí ele fala alto, grita, é autoritário, outro jeito. A tia dela, minha irmã, também sofre dos nervos e o meu filho também, consulta no psiquiatra de vez em quando e toma remédio da receita azul.

Numa família, se tem um que sofre, pode procurá que vai ter outro também, não tem?

Tem o nervo, vem de dentro, ataca pelos nervos da pessoa.

Quando deu a doença nela, passou para ele, os dedos ficavam duros, deformados. Ele tinha dez anos. Arreganhava os dedos assim [mostra, trançando uns sobre os outros], ficava durinho; ficou um tempo abalado. Ele é mais nervoso que ela, apesar de nunca ter tido ataque de nervos como ela. Acho que saíram assim porque eu tive eles muito nova, casei com 14 e com 15 nasceu o primeiro filho, os três primeiros foi com 11 mês cada, depois é que ficou cinco anos pra vim o outro, passei muito trabalho... Os dois são os mais problemáticos, os únicos que me dão problemas.

Acho que tem problemas com ela mesma, acho que isso é ter um sonho com ela mesma, sonhar com uma vida pra gente mesma, que a gente não tem, aí fica revoltada com a vida, com ela mesma, não tem? Tem muito problema dentro de si, que não passa para os outros, ela é muito sofrida, desde a infância; porque sabe como é, os filhos com os pais nunca se abrem, não dizem o que eles sentem...

Outras pacientes formulam mais explicações para a etiologia de seu sofrer:

Aífoi no centro espírita e eles disseram que foi um espírito que entrou nela e ela dizia mesmo, quando tava atacada: eu vim pra levar vocês, não vou deixar ninguém aqui não, vou levar todo mundo, fui mandado levar todos! Parecia mesmo que não era ela que falava, era um jeito mau que não é o jeito dela de falar. Dai eles fizeram um trabalho e livraram ela disso, nunca mais deu nada. 
Eu não sei se a senhora acredita nisso. Mas, sei lá... Parece que quando uma pessoa tem inveja assim, muita inveja de outra, ela pode provocar o mal pra outra, deixar doente, não sei, mas eu acho que é isso. Para mim só pode ser isso [mal provocado por inveja], porque eu mesma penso e todo mundo me diz isto: como é que eu posso ficar com a depressão, se eu não tenho razão pra isso? Minha vida agora tá boa, antes não, antes eu tinha motivo, né? Naquele tempo que ele bebia, botou tudo fora, mas agora, agora que a gente vive bem, tenho um pai-marido, que me deixa fazer tudo que eu quero: se eu quero comprar uma coisa eu compro, não preciso de ordem de ninguém [e esse pode ser o motivo de inveja de sua cunhada, cujo marido a subjuga].

Mais próxima da explicação freudiana está a paciente que localiza em traumas longínquos, sofridos na infância, a causa de seus padecimentos atuais:

Eu digo que meu problema vem da infância, sabes? Por quê? Porque eu não conheci a mãe, e tive uma infância muito sofrida, muito sofrida, muito trabalhada, fui muito maltratada, até eu mesma percebi com tudo isso, não tem? E muito sofrida pela minha madrasta, que a minha madrasta, que Deus me perdoe! (...) Mas sinto não poder [ajudar mais as pessoas, ter recursos para fazer isso]. Sinto também porque as pessoa não dão valor ao que eu faço, trago isso desde pequena, eu sempre percebi que os outros não dão valor, posso fazer o que for que ninguém liga se fui eu que fiz ou quem foi.

Para outras, a razão está na sua fraqueza para enfrentar o cotidiano, dizem não poder ver o sofrimento dos outros, brigas, encrencas familiares. Alegam também falta de amor, de carinho. Uma explicava que um sofrimento tão grande como o de nervos só poderia advir de praga de mãe.

Apenas uma paciente atribuiu seu sofrimento a um descontrole dos nervos passível de controle pessoal, dependendo, portanto, de ela mesma ter ou não o nervoso; no seu caso, dizia ter perdido o controle dos nervos por tristeza, após a morte de uma filha, pois, segundo ela, o nervo é a gente que faz.

As explicações derivadas da carência sexual apareceram apenas duas vezes, mencionadas pela mesma pessoa, uma nativa: uma vez, logo ao início da pesquisa, quando contou de sua mãe, insinuando que quando esta era mais nova e o pai saía para suas farras e amantes, deixava-a carente e, por isso, ela sofiia dos nervos; a segunda vez foi quando me apresentou uma paciente que já fora atendida em serviços médicos várias vezes e disse que, numa dessas:

o pessoal [a médica e os outros funcionários da Unidade de Saúde do Campeche] ficou dizendo que o que ela precisava era de homem, porque só se acalmou depois que o dentista chamou ela pra sua sala e ficou um tempão conversando com ela, ela já tinha consultado com a médica, por isso que ficaram falando que o negócio dela era falar com um homem, tadinha... Mas até parece que era mesmo, porque ficou bem melhor depois que ele conversou com ela. 
Porém, ao ser instada a falar mais sobre o assunto, ficou pensativa e então se corrigiu: "tadinha, acho que a gente pensou mal dela, talvez ela não tenha em quem confiar, pra quem desabafar... e o dentista é muito legal, ele sempre está disposto a conversar com quem vai lá".

Depoimentos das próprias pacientes fazem o contraponto à explicação baseada na falta de nervo (como diriam alguns ilhéus):

Quando está dando o problema dos nervos, eu nem quero nada de sexo, nem sinto nada; quando não, eu tenho relação normal, não é aquela fogosidade, mas é normal.

Aié que tá, gente nervosa, nervosa mesmo, que ansiedade todo mundo tem, mas quem sofre do problema nervo, lá dentro ela não é assim, não tem desejo sexual. Claro, eu posso estar um pouco nervosa e posso ter uma relação sexual e relaxar um pouco, mas ter aquele orgasmo que algumas dizem que tem, ah, isso não! (Paciente)

Se a pessoa está com um problema maior, ela nem consegue ter cabeça pra isso [para ter uma relação sexual], nem vai sentir nada (...) Mas quem tem a doença de nervo mesmo, aquela coisa estranha, aí não tem nada pra gozar, porque o nervo mesmo não tem nada pior do que isso. (Paciente)

Ao longo deste trabalho, procuro discutir o atendimento de tais casos, e como uma das hipóteses médicas é a que estabelece um paralelo entre a síndrome popular de nervos e a histeria, cumpre assinalar aqui que o estado de bem-estar na gravidez, dado como característico das histéricas (cf. Israël, 1995a), nem sempre aparece nas nervosas. Pelo contrário:

Todas as minha gravidez eu passava mal, desde o primeiro dia; naquele dia que ficava grávida parecia que acabou o mundo. Pra ficar grávida, ficava fácil; mas não sei se era dos nervo, depois... era dor demais, né? Ficar grávida era preparar o sofrimento, dor, mas dor mesmo, demais! E ficava abatida, tinha algo diferente, assim parece que acabou-se tudo para mim, os nervo decerto, só podia ser, nunca tinha dado pensamento nenhum em mim... Só pudia sê nervo, né? E foram sofridas, todas as minha gravidez foram sofridas. (Paciente)

Ela [a paciente] já não andava boa dos nervos e, aos seis meses de gravidez, o pai descobrin e ela ficou histérica, gritava com todos, passamos sufoco com ela. Ela se vingava, passava sem comer, dizia que ia morrer; o que valia era a amizade dela com a prima. (Mãe de uma paciente)

Todo mundo diz que eu rejeitei [a gravidez], que quando está na depressão sente, sente. Eu não sentia nada, eu só sentia vontade de não querer trabalhar, e não tomar banho, e não escovar dente, não sair de casa, ficar só deitada no sofá, é isso que eu sentia, mas nunca senti vontade de me matar, nunca! Agora não sei por que que me acontecia isso. As pessoas dizem que eu rejeitei, por isso fiquei daquele jeito, atacada dos nervos. (Paciente)

A gravidez? Cada uma era um sofrimento só! Eu passava os nove meses atacada, era direto aquela perturbação. Tem mulher que diz que essa é a época mais feliz da vida, pra mim não... quando sabia que tava grávida, eu já me desesperava, porque sabia o que ia passar. (Paciente) 
Coitadas! As que eu conheço que sofrem dos nervos parece que ficam pior na gravidez, ataca tudo, cada crise forte que nem sei! (Informante)

\title{
Calmantes e outras Mezinitas
}

\begin{abstract}
Bem no começo da minha doença, com 12 anos, a Vovozinha me benzia, me dava das fumaça das ervas $e$ fazia orações na minha roupa. Sabe, me sentia com uma paz dentro de mim, aquele cheiro de alecrim queimado me fazia relaxar e realmente melhorei por um bom tempo.
\end{abstract}

(Texto de uma paciente)

Para falar de tratamento dos nervos, é preciso que se tenha presente e se aceite a proposição antropológica de que os itinerários terapêuticos envolvem o uso múltiplo e simultâneo dos vários recursos disponíveis na sociedade. Aliás, nervos talvez seja um dos casos mais ilustrativos dessas duas características das possibilidades terapêuticas tomadas por alguém em busca de alívio para um sofrimento.

Atendendo a suas várias, sobrepostas e simultâneas, explicações para a doença, os pacientes recorrem da mesma forma a mais de um tipo de tratamento, simultânea ou sucessivamente. Assim, uma paciente vai ao médico no mesmo dia ou logo antes e, às vezes, logo depois de ter ido a um benzedor ou médium espírita. No primeiro, busca, principalmente, a exclusão ou a confirmação de causa orgânica, a receita de um calmante ou tranqüilizante (a famosa receita $a z u l){ }^{7}$ do segundo, espera solidariedade, compreensão, identificação com o problema e uma intermediação com o sobrenatural.

Essa intermediação pode acontecer na forma de rezas, nas quais se pede a cura ou o alívio da doença ou se implora perdão por faltas cometidas que possam ter gerado, como castigo, o sofrimento ora experimentado:

Eu acho que todo esse meu problema foi por causa de eu abortar uma filha, que até hoje eu não me esqueço, eu tenho a consciência pesada por isso. A primeira, a mais velha, que ela vai fazer 19 anos, e acho que ninguém esquece isso. Eu sei que isso é a causa da minha doença porque eu fui num centro lá no estreito e o médium disse que ele viu a minha filha, essa que eu abortei quando eu tinha 15 anos, atrás de mim e da irmã dela, ele disse que ela tem ciúme da irmã porque ela tá aqui na Terra com os pais. Eu não posso mais esquecer isso que eu fiz, por isso que sofro demais. Ele [o médium] está me ajudando, orando, pedindo perdão a Deus por mim, que eu era bem dizer criança quando aconteceu isso, o que que eu podia pensar, se era certo ou errado? (Paciente)

Agora eu estou com esperança de melhorar um pouco. Fui na Igreja Universal e o pastor me fez dar um testemunho, eu falei tudo de mim, do meu sofrimento, dos ataque que me dá, do aborto que fiz. É, eu fiz um aborto, tava com uma 
semana de gravidez e tomei uns chá, não sei por quê, mas fiz isso, sim, senhora [a afirmação é dirigida para a filha adolescente, que ouve estarrecida a confissão da mãe], os problemas da bebida do marido, da falta de dinheiro, tudo, a dificuldade com os filho que parece que eles não ligam para a mãe. Aí o pastor me disse que eu tava com câncer no estômago, que tudo que me dava de mau era por causa de um demônio dentro de mim, aí eu fiz. uma doação para a igreja e ele orou e me disse: a senhora tem que orar muito, não deixar a igreja. Agora eu tenho certeza que posso me curar, eu já me arrependi de tudo que foi mal que eu fiz, pedi perdão a Deus e ao pastor também. (Paciente)

O benzedor pede a Deus pela gente, reza pedindo forças pra ele, pra dá remédio certo e pra gente poder vencer os nervos. (Paciente)

Na consulta médica, a paciente busca alívio ou aval social para a sua condição e explicações sobre o seu sofrimento. Busca também um ouvinte solidário, que entenda do sofrimento e por isso seja capaz de lhe dar, se não a cura, ao menos a atenção de quem compreende o que ela está passando. Entretanto, esta última expectativa parece ser a mais frustrada, pois as queixas relativas ao descaso, à pressa, à incompreensão na consulta médica são muito freqüentes nas histórias dessas mulheres e de seus familiares.

A postura indiferente do médico contrasta fortemente com a dos outros agentes de cura, como os benzedores, por exemplo, que são freqüentemente lembrados pela sua paciência e compreensão. Era comum que, ao se referir a eles, as pacientes usassem expressões como "ele sabia do que eu estava falando...", "até parece que já tinha passado por isso". Indicavam, assim, de forma clara que seu sofrimento era perfeitamente compreensível e, por isso, aceitável para esses agentes, o que nem sempre acontecia com os médicos, sempre a insistir que isso [os nervos] não é nada!

Um aspecto sobre o qual médicos e profissionais de saúde insistem é o da possibilidade de controle por parte do paciente, mas isto contraria sua representação do problema dos nervos, que aos pacientes se afigura como uma situação totalmente fora de controle. No choque dessas representações, é impossível estabelecer uma relação terapêutica profícua.

Interessante notar que o descaso, real ou aparente, dos médicos pela condição de nervosa, longe de desestimular as crises, parece provocá-las ainda mais, principalmente quando se trata de obter receita azul ou aval para sua situação de doente crônica. Ir ao médico e tomar remédios, tanto quanto buscar outros recursos terapêuticos, atua sobre representações preexistentes, mas também cria e estimula a formação de novas representações. Tais representações tanto podem funcionar subsidiando positivamente o papel do doente e gerando atitudes propícias ao tratamento quanto podem favorecer o processo de cronificação e/ou de estigmatização.

As crises também são atendidas pelos parentes e vizinhos, que fazem a doente cheirar noz-moscada, tomar água com açúcar ou chás diversos (entre os quais os mais usados são de noz-moscada, que "é forte e faz sair logo da crise", de laranjeira, de erva- 
doce, de alecrim, "que é muito bom para os nervos", e o de hortelã) e a abanam, porque é comum que haja sufocação. Acudir uma pessoa em crise envolve também acalmá-la, aliviar-lhe a carga de trabalho ou de pensão (preocupação).

Assim, numa teia de esforços (pela cura) e reforços (à doença), tecidas por elas e pelos circunstantes, inclusive pelos agentes de cura, as nervosas vão sobrevivendo, mantendo seus nervos e confundindo seus médicos, num emaranhado de práticas religiosas e leigas nas quais se sustentam.

\section{NoTas}

1 Aos antropólogos, certamente, agradaria mais o termo sofredor; entretanto, a natureza ambígua deste trabalho me leva a preferir um de uso mais comum na medicina.

2 A filha, que tem um discurso muito psicologizado, compete com a mãe ao discursar sobre nervos, interrompendo a narrativa materna por várias vezes para contar de seu próprio sofrimento com nervos e como conseguiu controlá-lo "só com a força de vontade".

3 Esta paciente, por coincidência, fora amante recente do marido de outra, e era com seu nome que esta designava sua última crise. Interessante que na entrevista, que durou mais ou menos duas horas, ela afirmou, categórica, pelo menos por três vezes, não ter tido homem desde a separação do marido, que ocorrera perto de três anos antes.

$4 \quad$ As idas ao centro de saúde local ou ao posto de assistência médica da previdência social são todas mencionadas como idas ao posto.

5 Em medicina, especialmente na psiquiatria, tal sintoma é designado como bolo histérico.

6 Susto foi explicado como uma comoção muito forte, diante de um fato inesperado, que provoca um desequilíbrio funcional do corpo e da mente, provocando o aparecimento de qualquer um dos sintomas associados aos nervos. Não se observou aqui a caracterização de susto como perda da alma, tal como descrito em outros países da América Latina. Aqui, o termo se refere ao desequilíbrio fisiológico e afetivo provocado por um acontecimento inesperado e perturbador.

7 As normas de comercialização de medicamentos de ação psicotrópica no Brasil determinam que sua prescrição seja controlada por meio do uso de um formulário de cor azul, o qual, por omissão (e às vezes por ignorância médica), acaba substituindo a própria receita médica (que poderia ser em papel de qualquer cor). Assim, o formulário de controle acabou sendo popularmente conhecido como receita azul. 